\title{
The performance of a library in improving reading culture during the Covid-19 pandemic
}

\author{
A. Asari*, R. Mahdi, D. Widyartono, P.D. Anggari, A. Prasetyawan, K.M. Raharjo, \\ A.B.N.R. Putra \& I.A. Zakaria \\ Universitas Negeri Malang, Malang, Indonesia
}

\begin{abstract}
The research aims to describe the strategy of the library in improving the reading culture and to find out what factors affect the performance of library services in increasing public interest in reading during a pandemic. The research method used is the descriptive method using surveys and interviews as well as qualitative analysis. Data was obtained through questionnaires, interviews and observations. The research was conducted in the library of state universities in Malang City. The results showed that the performance of library services in improving reading mints was not optimal; it was indicated that there were still user complaints, the attitude of service officers was not fully responsive and information on service programs was not widely known by users.
\end{abstract}

Keywords: performance, service, library, interest in reading

\section{INTRODUCTION}

Libraries as public service institutions should be obliged to provide the best service for the community. Therefore, fundamental changes are needed, especially in terms of improving the quality or performance of library services that are more oriented towards community service satisfaction and are responsive to the dynamics of the service environment, meaning trying to provide the best service and evaluate it based on the point of view of library service users (Yi \& Cong 2018). So far, the attitudes and behavior of library service providers are more oriented to the needs of institutions and superiors who tend to be served, thus neglecting services to users (Kiran \& Diljit 2017).

In this regard, the quality or performance of professional library services needs to be realized, service officers as human resources in the library who are the spearheads in providing services to users are required to provide quality services and are more oriented towards user satisfaction and are more responsive to challenges and opportunities (Murray \& Hackathorn 2016). They must not be fixated on routine activities, have the competence to provide fair services and empower the community so that it can create a society that has a high level of literacy (Kotler 2002.).

According to a theoretical perspective, there has been a shift in the public service paradigm from a traditional public administration model to a new public management model, and finally to a new public service model (Piatak \& Holt 2020). In the new public service model, public interests are formulated as a result of dialogue from various sources that exist in society and public services must be responsive to various interests and must be non-discriminatory (Subarsono 2005).

According to Sulistyo-Basuki, services in library science can be interpreted as an activity related to providing information by librarians to users (Basuki 2020). Public services in libraries must also be supported by the competencies that librarians must-have. Sudarsono, B. (2020) identifies the competencies that must be owned, namely: (1) knowing the basis of organizing; (2) having and knowing suitable and effective reference interview techniques; (3) knowing printed and digital information resources; (4) having the ability to provide suggestions and directions to users; (5) being

\footnotetext{
*Corresponding author: andi.asari.fs@um.ac.id
} 
able to design and implement information retrieval strategies; and (6) able to guide users in the interpretation and evaluation of information.

According to Abbot in Sulistyo Basuki (Sulistyo-Basuki 2004) in simple terms library performance indicators are management tools designed to help library managers determine how good their service performance is. A librarian/service officer is the spearhead in providing quality services to the user community (Basuki 2020). The assessment of the performance of librarians/service officers is one of the most important elements in assessing library performance. This is in line with what was stated by GT. Milkovich and JW Boudreau (Aye \& Nusari 2019), who revealed that performance appraisal is a process carried out to assess employee performance while employee performance is defined as a level where employees meet/achieve specified work requirements.

Levine (2014) suggests three concepts that can be used as a reference for measuring the performance of public organizations, namely responsiveness (responsiveness), responsibility (responsibility), and accountability (accountability). Apart from these three performance indicators, it is also common to use other indicators that are more specific according to Mulyadi and Setiawan (Tangkilisan 2005), namely: (1) building customer satisfaction; (2) having employee work productivity; and (3) generating adequate financial returns. Parasuraman, et al. (2001) identified ten main dimensions in assessing the performance/quality of public services, namely reliability, responsiveness, competence, access, politeness, communication, credibility, security, ability to understand customers and physical evidence.

\section{METHODS}

The research method used was a descriptive research method using surveys, in-depth interviews and qualitative design (Hernon 2008). Descriptive research is intended for careful measurement of certain social phenomena. (Noble \& Smith 2015). Descriptive research is a form of research that is most basic, aimed at describing existing phenomena, both natural phenomena and human engineering (Brinkmann, \& Kvale 2015).

The variables in this study were the elements of performance measurement of library services, which consist of responsiveness, reliability, service ethics, and service facilities. In this study, data collection was carried out in several ways, including interviews, which were conducted using an interview guide that was focused and flexible. Interviews were needed to deepen various interpretations, perceptions, and perspectives from various policies related to existing discussion topics. Interviews conducted in this study included interviews with library users and library service providers, namely elements of library leaders and library service officers or librarians. In addition to interviews, data collection was strengthened by distributing questionnaires in the form of questions that have been designed in such a way by researchers and addressed to library users with questionable material regarding performance indicators including responsiveness, reliability, service ethics, and service facilities. Then, the results was analyzed by simple descriptive statistics. The final data collection used observation, namely the collection of field data by looking at the performance of library services and the atmosphere of college libraries in Malang City which also affect the performance of library services.

\section{RESULTS AND DISCUSSION}

Libraries as one of the public service institutions are required to provide optimal performance to improve the reading culture and meet the needs of the user community. With performance appraisal, it can be evaluated to what extent the quality of library service performance in improving the reading culture of the community was. The indicators used to measure the performance of library services include dimensions of reliability. These dimensions are analyzed and interpreted as follows.

\subsection{Procedures and timeliness of service}

Easy service procedures measure the reliability in providing services to library users in supporting the development of a reading culture. 
Table 1. Ease of service procedures.

\begin{tabular}{|c|c|c|c|c|c|c|}
\hline \multirow[b]{2}{*}{ Kind of service } & \multicolumn{3}{|c|}{ User Complaints } & \multicolumn{3}{|c|}{ Amount } \\
\hline & yes & & not & & & \\
\hline & $\mathrm{f}$ & $\%$ & $\mathrm{f}$ & $\%$ & $\mathrm{f}$ & $\%$ \\
\hline Member registration & 89 & 90.8 & 9 & 9.2 & 98 & 100.0 \\
\hline Catalogs and references & 67 & 68.4 & 31 & 31.6 & 98 & 100.0 \\
\hline Borrowing books & 62 & 63.3 & 36 & 36.7 & 98 & 100.0 \\
\hline Borrowing newspapers and magazines & 69 & 70.4 & 29 & 29.6 & 98 & 100.0 \\
\hline
\end{tabular}

Table 2. Timeliness of service.

\begin{tabular}{lcccccc}
\hline & \multicolumn{3}{c}{ User Complaints } & & \multirow{2}{*}{ Amount } \\
\cline { 2 - 5 } Kind of service & yes & \multicolumn{2}{c}{ not } & & \\
\hline & $\mathrm{f}$ & $\%$ & $\mathrm{f}$ & $\%$ & $\mathrm{f}$ & $\%$ \\
Member registration & 88 & 89.8 & 10 & 10.2 & 98 & 100.0 \\
Catalogs and references & 72 & 73.5 & 26 & 26.5 & 98 & 100.0 \\
Borrowing books & 63 & 64.3 & 35 & 35.7 & 98 & 100.0 \\
Borrowing newspapers and magazines & 73 & 74.5 & 25 & 25.5 & 98 & 100.0 \\
\hline
\end{tabular}

Table 3. Completeness of the collection.

\begin{tabular}{lcccccc}
\hline & \multicolumn{3}{c}{ Complete collection } & \multicolumn{2}{c}{ Amount } \\
\cline { 2 - 6 } Collection type & \multicolumn{2}{c}{ yes } & \multicolumn{2}{c}{ not } & & \\
\hline & $\mathrm{f}$ & $\%$ & $\mathrm{f}$ & $\%$ & $\mathrm{f}$ & $\%$ \\
Book & 41 & 41.8 & 57 & 58.2 & 98 & 100.0 \\
Magazine & 44 & 44.9 & 54 & 55.1 & 98 & 100.0 \\
Newspaper & 68 & 69.4 & 30 & 30.6 & 98 & 100.0 \\
\hline
\end{tabular}

However, in reality, service procedures have not fully demonstrated reliability in providing services to users, especially in terms of procedures for borrowing books. As many as $36.7 \%$ of users stated that the book borrowing procedure had not made it easy, regarding the lack of convenience in service procedures. The procedures for the retrieval of information both through card catalogs and OPAC catalogs are still considered quite difficult for users.

Timeliness of service is where the implementation of public services can be completed within a predetermined period (KepMenPan 81/1995). Indicators of timeliness of service include timeliness of member registration services, catalogs, and references, borrowing books, borrowing newspapers and borrowing magazines (Table 2).

The survey results show that the punctuality of service has not shown optimal performance. Especially for the book lending service, $35.7 \%$ of users still stated that there was no timeliness of service in getting the collection to be borrowed and in catalog and referral services as many as $26 \%$ of users stated that the service was not on time. Meanwhile, $35.7 \%$ of users stated that the service time for borrowing books was not on time, this is related to the book lending procedure, where users still have to wait a long time to get the books they need so that users do not get certainty of service time.

\subsection{Completeness, accuracy, and up-to-date collection}

Then the indicators of the completeness of the collection consist of the completeness of the collection of books, magazines, and newspapers/newspapers (Table 3 ). 
Table 4. Collection accuracy.

\begin{tabular}{lcccccc}
\hline & \multicolumn{3}{c}{ Complete collection } & \multicolumn{2}{c}{ Amount } \\
\cline { 2 - 5 } Collection type & \multicolumn{2}{c}{ yes } & \multicolumn{2}{c}{ not } & & \\
\hline & $\mathrm{f}$ & $\%$ & $\mathrm{f}$ & $\%$ & $\mathrm{f}$ & $\%$ \\
Book & 45 & 45.9 & 53 & 54.1 & 98 & 100.0 \\
Magazine & 59 & 60.2 & 39 & 39.8 & 98 & 100.0 \\
Newspaper & 76 & 77.6 & 22 & 22.4 & 98 & 100.0 \\
\hline
\end{tabular}

Table 5. Recent collections.

\begin{tabular}{lcccccr}
\hline & \multicolumn{3}{c}{ Up-to-date collection } & \multicolumn{2}{c}{ Amount } \\
\cline { 2 - 5 } Collection type & \multicolumn{2}{c}{ yes } & \multicolumn{2}{c}{ not } & & \\
\hline & $\mathrm{f}$ & $\%$ & $\mathrm{f}$ & $\%$ & $\mathrm{f}$ & $\%$ \\
Book & 37 & 37.8 & 61 & 62.2 & 98 & 100.0 \\
Magazine & 59 & 60.2 & 39 & 39.8 & 98 & 100.0 \\
Newspaper & 79 & 80.6 & 19 & 19.4 & 98 & 100.0 \\
\hline
\end{tabular}

The table above shows that most of the users stated that the collections in the library were incomplete. Especially for book collections, as much as $58.2 \%$ of users stated that the book collection was incomplete and for magazine collections as much as $55.1 \%$ of the respondents stated that it was incomplete. Due to the large number of users who stated that the collections of higher education libraries in Malang City were not complete. An accurate library collection is a reflection that the user's information needs can be met. Collection accuracy indicators include the accuracy of the collection of books, magazines and newspapers (Table 4).

In reality, the existing collections have not fully fulfilled the user's information needs. As many as $54.1 \%$ of users stated that the existing book collections were inaccurate, that is, they were not relevant to the user's information needs. This is closely related to the incompleteness of the existing collections. Where the policies in the development of collections are more emphasized in the fields of social sciences and humanities which have not been socialized to users. The current library collection is one of the determining factors in the performance of library services. Where the library must be able to anticipate the information needs of its users, which are dynamic and always changing, following changes in social values in society, through efforts to develop the latest collections, the library can meet the needs of its users. The indicators of up-to-date collections include the latest collections of books, magazines, and newspapers (Table 5).

In terms of the updating of book collections, the majority of users (62.2\%) stated that the existing book collections were not up to date. The lack of sophistication of this collection is related to the procurement of library collections that must be guided by government policies through Presidential Decree No. 17 of the year 1980 regarding the system for procurement of goods that must go through vendors and partners. So that the development of library collections is difficult to meet the needs of users for current collections. Not to mention the collection processing process which still takes quite a long time.

\subsection{Service personnel communication skills}

Indicators of the communication skills of service officers consist of the communication skills of information service officers, member registration, the borrowing of books, and the borrowing of newspapers and magazines, catalogs, and references (Table 6).

In general, the table above shows that most of the users stated that existing service officers had good communication skills. Especially in the case of member registration services, where as many as $86.7 \%$ of users stated that service officers had good communication skills. However, there were still quite a lot of users who stated that service officers did not have communication skills, namely 
Table 6. Communication skills of library service officers.

\begin{tabular}{lcccccc}
\hline & \multicolumn{3}{c}{ Communication skills } & & \multirow{2}{*}{ Amount } \\
\cline { 2 - 5 } Service attendant & \multicolumn{2}{c}{ yes } & \multicolumn{2}{c}{ not } & & \\
\hline & $\mathrm{f}$ & $\%$ & $\mathrm{f}$ & $\%$ & $\mathrm{f}$ & $\%$ \\
Information service & 69 & 70.4 & 29 & 29.6 & 98 & 100.0 \\
Member registration & 85 & 86.7 & 13 & 13.3 & 98 & 100.0 \\
Catalogs and references & 66 & 67.3 & 32 & 32.7 & 98 & 100.0 \\
Borrowing books & 67 & 68.4 & 31 & 31.6 & 98 & 100.0 \\
Borrowing newspapers and magazines & 62 & 63.3 & 36 & 36.7 & 98 & 100.0 \\
\hline
\end{tabular}

as many as $36.7 \%$ of users stated that newspaper and magazine loan service officers still did not have good communication skills.

\section{CONCLUSION}

The development of existing collections has not been able to meet the needs of the user community, especially for the type of book collection. University libraries in Malang City are still late in providing collections, the sophistication of collections in libraries is not the same as the sophistication of collections circulating outside the library. This is related to the collection development system which is still fixated on the rules of the procurement system so that collection development always experiences delays. On the other hand, the time-consuming processing of library materials also plays a role in providing up-to-date collections.

\section{REFERENCES}

Aye, T., Ameen, A., \& Nusari, M. 2019. Factors influencing job performance of employees from international non-profit organizations in Myanmar. International Journal on Recent Trends in Business and Tourism (IJRTBT), 3(2), 56-68.

Basuki, S. 2020. Profesi Dan Konsep Pustakawan Dalam Konteks Indonesia. Media Pustakawan, 17(1\&2), 75-83.

Brinkmann, S., \& Kvale, S. 2015. Interviews: Learning the craft of qualitative research interviewing (Vol. 3). Thousand Oaks, CA: Sage.

Hernon, P., \& Schwartz, C. 2008. Leadership: Developing a research agenda for academic libraries. Library \& Information Science Research, 30(4), 243-249.

Kiran, K., \& Diljit, S. 2017. Antecedents of customer loyalty: Does service quality suffice?. Malaysian Journal of Library \& Information Science, 16(2), 95-113.

Kotler, Philip. 2002. Manajemen Pemasaran. Jakarta : Prehaliilindo.

Levine, S. S., \& Prietula, M. J. 2014. Open collaboration for innovation: Principles and performance. Organization Science, 25(5), 1414-1433.

Lubis, Ella H. 1999. Penilaian kinerja individu (performance Appraisal). Jurnal Usahawan No. 11 TH XXVIII. (34-36).

Murray, A., Ireland, A., \& Hackathorn, J. 2016. The value of academic libraries: Library services as a predictor of student retention. College \& Research Libraries, 77(5), 631-642.

Noble, H., \& Smith, J. 2015. Issues of validity and reliability in qualitative research. Evidence-based nursing, 18(2), 34-35.

Piatak, J. S., \& Holt, S. B. 2020. Prosocial behaviors: A matter of altruism or public service motivation?. Journal of Public Administration Research and Theory, 30(3), 504-518.

Subarsono, A. G. 2005. Analisis kebijakan publik: konsep, teori dan aplikasi (Vol. 138). Pustaka Pelajar.

Sulistyo-Basuki. 2004. Pengantar Dokumentasi. Bandung: Rekayasa Sain.

Sudarsono, B. 2020. Pustakawan dan Perpustakaan dalam menghadapi tantangan di Era Global. Media Pustakawan, 18(3), 1-8.

Tangkilisan, Hessel Hogi S. 2005. Manajemen publik. Jakarta: Grasindo.

Yi, K., Chen, T., \& Cong, G. 2018. Library personalized recommendation service method based on improved association rules. Library Hi Tech. 